\title{
Seasonal and spatial variability of surface ozone over China: contributions from background and domestic pollution
}

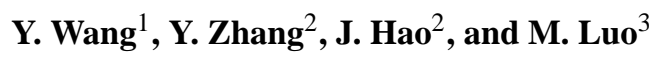 \\ ${ }^{1}$ Ministry of Education Key Laboratory for Earth System Modeling, Center for Earth System Science, Institute for Global \\ Change Studies, Tsinghua University, Beijing, China \\ ${ }^{2}$ School of Environment, Tsinghua University, Beijing, China \\ ${ }^{3}$ Jet Propulsion Laboratory, California Institute of Technology, Pasadena, California, USA
}

Received: 2 November 2010 - Published in Atmos. Chem. Phys. Discuss.: 15 November 2010

Revised: 23 March 2011 - Accepted: 3 April 2011 - Published: 15 April 2011

\begin{abstract}
Both observations and a 3-D chemical transport model suggest that surface ozone over populated eastern China features a summertime trough and that the month when surface ozone peaks differs by latitude and region. Source-receptor analysis is used to quantify the contributions of background ozone and Chinese anthropogenic emissions on this variability. Annual mean background ozone over China shows a spatial gradient from $55 \mathrm{ppbv}$ in the northwest to $20 \mathrm{ppbv}$ in the southeast, corresponding with changes in topography and ozone lifetime. Pollution background ozone (annual mean of $12.6 \mathrm{ppbv}$ ) shows a minimum in the summer and maximum in the spring. On the monthly-mean basis, Chinese pollution ozone (CPO) has a peak of 20-25 ppbv in June north of the Yangtze River and in October south of it, which explains the peaks of surface ozone in these months. The summertime trough in surface ozone over eastern China can be explained by the decrease of background ozone from spring to summer (by -15 ppbv regionally averaged over eastern China). Tagged simulations suggest that long-range transport of ozone from northern mid-latitude continents (including Europe and North America) reaches a minimum in the summer, whereas ozone from Southeast Asia exhibits a maximum in the summer over eastern China. This contrast in seasonality provides clear evidence that the seasonal switch in monsoonal wind patterns plays a significant role in determining the seasonality of background ozone over China.
\end{abstract}

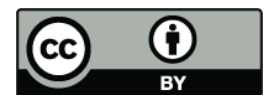

Correspondence to: Y. Wang

(yxw@tsinghua.edu.cn)

\section{Introduction}

Many nations set ambient air quality standards for surface ozone and regulate anthropogenic emissions of ozone precursors in order to protect public health and vegetation from the adverse effects of ozone pollution. Domestic pollution controls, however, will have little effect on the amount of ozone subsided or advected horizontally from outside the boundary layer. The background represents not only the natural concentrations of $\mathrm{O}_{3}$ (the natural background produced from natural precursor sources or originated from the stratosphere) but also contributions from the long-range transport of $\mathrm{O}_{3}$ produced from non-domestic anthropogenic emissions. Through global model simulations, background ozone over the US is estimated at $15-35$ ppbv on average in the summer, including important contributions from anthropogenic pollutions of neighboring countries (Fiore et al., 2002; H. Wang et al., 2008).

The rising emissions from fossil fuel combustion in China are expected to increase surface concentrations of $\mathrm{O}_{3}$ over the source region as well as the background of $\mathrm{O}_{3}$ over other parts of the world. Despite the importance of changing anthropogenic emissions in China on the budget of tropospheric ozone over East Asia and globally, some fundamental understanding about ozone, such as its origin, spatial distribution, and seasonal variations, has yet to be studied through combined efforts of observation and modeling for China. Seasonal variations in surface ozone have been measured at a limited number of Chinese sites. Although these observations tend to suggest seasonal patterns diff from site to site, they share one common feature that surface ozone over China does not have a distinct peak in mid-summer

Published by Copernicus Publications on behalf of the European Geosciences Union. 
(July or August) in contrast to the pattern observed typically in the US. A number of previous studies suggested that the summer monsoon had significant influence on summertime ozone over China. Surface ozone observed at a rural site (Miyun) near Beijing in July was found to have a good anticorrelation with cloud optical depths retrieved from MODIS (Y. Wang et al., 2008). The Model Inter-Comparison Study for Asia (MICS-Asia) project suggested that it was a typical problem for models to underestimate ozone in the lowest $2.5 \mathrm{~km}$ over East Asia (Han et al., 2008). Lin et al. (2009) conducted multi-scale model simulations of boundary layer ozone over East Asia and evaluated models' performance in response to the choice of chemical mechanism, dynamics and resolution. They found that simulation of summertime ozone over central east China is highly sensitive to the treatment of cloud cover and rainfall in the model. Zhao et al. (2010) established the spatial and temporal relationship between satellite-derived observations of precipitation patterns and tropospheric ozone abundance over East Asia, in support of the monsoonal influence. Although these studies demonstrated that summertime ozone over China is strongly influenced by the summer monsoonal circulation, the underlying mechanism has not been well quantified. A question of interest is the extent to which summer monsoon affects in situ production of ozone from regional sources as well as the transport of ozone from outside. A quantitative understanding of the relative contributions from the background and domestic anthropogenic sources on surface ozone over China will shed some light to this topic. It also has important implications for risk assessment and control strategies. After all, China is susceptible to anthropogenic emissions from other regions, in particular Europe (Newell and Evans, 2000) and neighboring countries in Asia. Several studies have examined the contributions from European and North American anthropogenic emissions to the background $\mathrm{O}_{3}$ over Japan (Wild and Akimoto, 2001; Akimoto, 2003; Wild et al., 2004), over East Asia as a whole (Holloway et al., 2008; Nagashima et al., 2010; Fiore et al., 2009), and to the Asian outflow to the Pacific (Bey et al., 2001b; Liu et al., 2002), but little analysis has been conducted for their impacts on the background $\mathrm{O}_{3}$ over China.

The present study uses a 3-D global model of tropospheric chemistry (GEOS-Chem) and its nested-grid version over East Asia to investigate some general features of the seasonal and spatial variations of surface $\mathrm{O}_{3}$ over China and to identify contributions of various source types (natural and anthropogenic) and regions (domestic and foreign) to its spatial distribution and seasonality. We begin in Sect. 2 by describing the atmospheric chemistry transport model adopted in our study. We then examine in Sect. 3 the ability of the model to reproduce key features of ozone observed upwind, downwind, and within China. Source-receptor analysis is conducted in Sect. 4 to quantify the contributions from background and domestic anthropogenic emissions on the spatial and seasonal patterns of surface ozone over China. In Sect. 5, tagged tracer simulations are discussed to evaluate the contributions on surface ozone by source regions. The concluding remarks are given in Sect. 6.

\section{Model description}

The nested-grid GEOS-Chem model of tropospheric chemistry developed by Wang et al. (2004a) and Chen et al. (2009) is employed in the present study. The GEOS-Chem model is driven by meteorological data assimilated by the Goddard Earth Observing System (GEOS) at the NASA Global Modeling and Assimilation Office (GMAO). The present study uses GEOS-5 meteorology covering the period from December 2004 to present. The GEOS-Chem model includes a detailed tropospheric $\mathrm{O}_{3}-\mathrm{NO}_{\mathrm{x}}$-hydrocarbon- aerosol simulation. The aerosol and oxidant chemistry are coupled through the formation of sulfate and nitrate, heterogeneous chemistry, and aerosol effects on photolysis rates (Bey et al., 2001a; Park et al., 2004). The structure of the nested-grid GEOSChem model involves a window with a uniform horizontal resolution of $0.5^{\circ} \times 0.667^{\circ}$ embedded in a low-resolution $\left(4^{\circ} \times 5^{\circ}\right)$ global background. The nested-grid GEOS-Chem retains the generic high horizontal resolution of the GEOS-5 data over the nested regional domain. For the present study, the nested domain is set at $70^{\circ} \mathrm{E}-150^{\circ} \mathrm{E}$ and $11^{\circ} \mathrm{S}-55^{\circ} \mathrm{N}$ and includes all of China, its neighboring countries, and a significant portion of the northwestern Pacific. The highresolution regional simulation is coupled dynamically to the low-resolution global model through lateral boundary conditions that are updated every three hours.

GEOS-Chem global runs uses national emission inventories for anthropogenic sources where available, and otherwise the base emission inventory of 1985 from the Global Emission Inventory Activity (GEIA) (Benkovitz et al., 1996) for $\mathrm{NO}_{\mathrm{x}}$ which is scaled by country on the basis of energy statistics to 2006 as described by Bey et al. (2001a), the nonmethane hydrocarbon inventory from Piccot et al. (1992), and the CO emissions from Wang et al. (1998a). Anthropogenic emissions of $\mathrm{NO}_{\mathrm{x}}, \mathrm{CO}, \mathrm{SO}_{2}$, and VOCs over East Asia were taken from the bottom-up inventory of Streets et al. (2003) for 2001 and Zhang et al. (2009) for 2006. Soil $\mathrm{NO}_{\mathrm{x}}$ emissions are computed in GEOS-Chem using a modified version of the algorithm proposed by Yienger and Levy (1995). The exception is for east China, for which the model includes seasonally resolved soil $\mathrm{NO}_{\mathrm{x}}$ emissions (1.63 $\mathrm{Tg} \mathrm{N} \mathrm{yr}^{-1}$ ) derived based on multi-year GOME satellite observations of tropospheric $\mathrm{NO}_{2}$ columns up to 2000 (Wang et al., 2007a). Lightning emissions follow Price and Rind (1992), with the $\mathrm{NO}_{\mathrm{x}}$ shape profile proposed by Pickering et al. (1998). The monthly flash rate is constrained by the monthly climatology for 1995-2005 based on the OTD/LIS measurements, while the flash rate and location within the month is allowed to vary with convection (Sauvage et al., 2007). Biomass burning emissions are taken 
from the GFED-2 inventory (van der Werf et al., 2006). Biogenic emissions of NMVOCs are adopted from the MEGAN inventory (Guenther et al., 2006).

The simulation using emissions described above is referred to as the standard simulation. Two sensitivity simulations were conducted in which we removed all anthropogenic emissions of $\mathrm{NO}_{\mathrm{x}}, \mathrm{CO}$, and nonmethane hydrocarbons (1) within China, or (2) globally both in the nestedgrid model and in the coarser-resolution global model which provides proper boundary conditions. Natural sources $\left(\mathrm{NO}_{\mathrm{x}}\right.$ from soil and lightning, biogenic VOCs, etc.) and biomass burning emissions remain unchanged. Sensitivity simulation 1 gives ozone levels that would exist in the absence of Chinese anthropogenic emissions, that is, total background $\mathrm{O}_{3}$ (TBO) over China. Sensitivity simulation 2 gives the natural background of $\mathrm{O}_{3}$ (NBO) over China, while the differences between sensitivity 1 and 2 represent pollution background $\mathrm{O}_{3}(\mathrm{PBO})$ or the enhancement of $\mathrm{O}_{3}$ resulting from anthropogenic emissions outside of China. The differences between the standard simulation and sensitivity simulation 1 are attributed to the ozone enhancement due to Chinese anthropogenic emissions, referred to as Chinese pollution ozone (CPO) in this study. Given the rapid growth of Chinese anthropogenic emissions, CPO for present day may be higher than what reported in this study which used 2006 Chinese emissions. Table 1 summarizes different sets of simulations conducted in this study. The modeling approach follows Fiore et al. (2002) and is similar to the concept of source-receptor analysis which describes the sensitivity of surface ozone to a change in emissions from a source region or source category. Based on this modeling approach, the following relationships will hold for surface ozone of the standard simulation (referred hereafter as to total ozone or $\mathrm{TO}): \mathrm{TO}=\mathrm{TBO}+\mathrm{CPO}$, where $\mathrm{TBO}=\mathrm{NBO}+\mathrm{PBO}$.

For the standard and sensitivity simulations, the lowresolution $\left(4^{\circ} \times 5^{\circ}\right)$ global model was spun-up for a 12 month period beginning 1 January 2005 . Concentration fields on 1 December 2005 were then interpolated onto the high-resolution $\left(0.5^{\circ} \times 0.667^{\circ}\right)$ nested-domain over East Asia to initiate the nested-grid simulation. Both models were run from December 2005 to the end of 2006, with the global simulation providing lateral boundary conditions to drive the nested-grid model simulation. Results for 2006 from the nested-grid simulation will be presented for analyses in Sects. 4 and 5. In Sect. 3, we also presented the standard nested-grid model results for 2001 (Wang et al., 2004a, b) to compare with the aircraft observations in 2001 .

\section{Model evaluation}

Application and evaluation of the GEOS-Chem model over and around China has been described by Wang et al. (2004a, b, 2007a, b) for CO and species of the reactive nitrogen family. In this work, we focus our evaluation on $\mathrm{O}_{3}$ in order to diagnose the strengths and weakness in the model through comparisons with the following observations. The ability of the model to simulate seasonal variations in $\mathrm{CO}$ is presented as an additional evaluation of the model's transport. For model evaluation, we focus on the nested-grid model results for 2001 and 2006 when observations were available.

\subsection{Surface $\mathrm{O}_{3}$ and $\mathrm{CO}$ in east Siberia}

Continuous measurements of $\mathrm{O}_{3}$ and $\mathrm{CO}$ were made for three years (1997-1999) at Mondy $\left(51^{\circ} 39^{\prime} \mathrm{N}, 100^{\circ} 55^{\prime} \mathrm{E}\right.$, 2006 m a.s.1.), a remote mountain site in East Siberia (Pochanart et al., 2003). Measurements at the Mondy site have been analyzed to define the inflow of trace gases to the East Asia Pacific rim region (Pochanart et al., 2003) and to quantify the trans-Eurasian international transport of air pollutants from Europe to East Asia (Wild et al., 2004). Figure 1 compares nested-grid model results for 2001 and observed monthlymean concentrations of $\mathrm{O}_{3}$ (a) and $\mathrm{CO}$ (b) at the Mondy site. Monthly mean $\mathrm{O}_{3}$ peaks in spring with a minimum in late summer early fall. Monthly mean $\mathrm{CO}$ has a maximum in spring and minimum in summer. Pochanart et al. (2003) attributed the spring maximum of $\mathrm{CO}$ at Mondy to the impact of forest fires in Siberia. The model successfully reproduces the mean mixing ratios of both species as well as their seasonal variations. There are minor negative biases (about $-3 \mathrm{ppb}$ ) for $\mathrm{O}_{3}$ except in winter. $\mathrm{CO}$ is well reproduced by the model for most months. Only notable discrepancies are a negative bias of $20 \mathrm{ppbv}$ in December and positive bias of 20 ppbv in January. The discrepancy may be due partly to the fact that the model results (2001) are not sampled for the specific time when measurements were made (1997-1999). As the Mondy site is located close to the northwest boundary of the nested domain, the comparison leads confidence to the dynamic boundary conditions provided from the global lowresolution simulation and verifies that the configuration of the nested-grid simulation adopted here is suitable for studying the intercontinental transport of pollutants from Europe to East Asia.

\subsection{Seasonal variations of $\mathrm{O}_{3}$ and $\mathrm{CO}$ at Chinese sites}

Year-round measurements of $\mathrm{O}_{3}$ and $\mathrm{CO}$ at only a few nonurban sites in China are available from literature. We selected three representative surface sites for model comparison: a remote coastal site (Hok Tsui, Hong Kong) in the Pearl River Delta region (PRD) $\left(22^{\circ} 13^{\prime} \mathrm{N}, 114^{\circ} 15^{\prime} \mathrm{E}, 60 \mathrm{~m}\right.$ a.s.l.) (Wang et al., 2009), a rural site (Lin An) in the Yangtze River Delta region (YRD) $\left(30^{\circ} 25^{\prime} \mathrm{N}, 119^{\circ} 44^{\prime} \mathrm{E}, 132 \mathrm{~m}\right.$ a.s.l.) (Wang et al., 2001, 2002), and a rural site (Miyun) in the North China Plain (NCP, $40^{\circ} 29^{\prime} \mathrm{N}, 116^{\circ} 46.45^{\prime} \mathrm{E}, 152 \mathrm{~m}$ a.s.l.) (Y. Wang et al., 2008, 2010b). The three sites, which are roughly $10^{\circ}$ latitude apart and spread from south to north China, cover three fast-developing regions in China, namely the Pearl River Delta, Yangtze River Delta, and the Beijing- 
Table 1. Simulation used in the study.

\begin{tabular}{ll}
\hline Name & Description \\
\hline 1.Standard simulation & Anthropogenic and natural emissions as described in the text (Sect. 2) \\
2. China total background ozone & Same as 1 but without the Chinese anthropogenic emissions \\
3. Natural background & Same as 1 but without the global anthropogenic simulation \\
4. Tagged ozone simulation & Driven by daily production and loss frequency of ozone \\
& files archived from simulation 1 \\
\hline
\end{tabular}
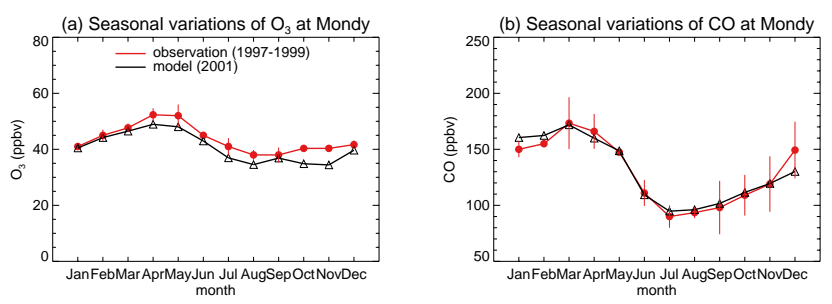

Fig. 1. Monthly mean $\mathrm{O}_{3}$ (a) and $\mathrm{CO}$ (b) mixing ratios (ppbv) of observation (red circles) and model (black triangels) at the Mondy site.

Tianjin-Tangshan city clusters. In addition, monthly-mean ozone observations at three mountain sites are also used: Mount Tai $\left(36.25^{\circ} \mathrm{N}, 117.10^{\circ} \mathrm{E}, 1533 \mathrm{~m}\right.$ a.s.1), Mount Hua $\left(34.49^{\circ} \mathrm{N}, 110.09^{\circ} \mathrm{E}, 2064 \mathrm{~m}\right.$ a.s.l) and Mount Huang $\left(30.13^{\circ} \mathrm{N}, 118.15^{\circ} \mathrm{E}, 1836 \mathrm{~m}\right.$ a.s.1.), all located in east China with continuous measurements of ozone from March 2004 to February 2005 (Li et al., 2007). The locations of these sites are shown in Fig. 7.

Seasonality of surface $\mathrm{CO}$ and $\mathrm{O}_{3}$ at these sites is summarized in Fig. 2. Monthly mean $\mathrm{CO}$ observed at the three surface sites (Fig. 2a-c) exhibits maxima in winter, resulting from increased lifetime of $\mathrm{CO}$ coupled with enhancement in regional emissions from residential heating. $\mathrm{CO}$ at Hok Tsui and Lin An has a minima in summer, while CO peaks in July at Miyun resulting from seasonal burning of crop residues after the harvest of winter wheat (Y. Wang et al., 2008, 2010b). Surface ozone exhibits distinctively different seasonality at the three surface sites (Fig. 2d-f). It peaks in autumn at Hok Tsui, in May at Lin An, and in June at Miyun. At the peak month, mean mixing ratio of $\mathrm{O}_{3}$ increases from south to north, from $48 \mathrm{ppbv}$ at Hok Tsui, to $58 \mathrm{ppbv}$ at Lin An, and to $67 \mathrm{ppbv}$ at Miyun. Ozone observation at Mt. Tai (Fig. 2g) and Mt. Hua (Fig. 2h) shows a peak in June and a low value in August, similar to surface ozone seasonality observed at Miyun as they are all located north of the Yangtze River. Ozone at Mt. Huang (Fig. 2i) exists at peak values both in late spring and autumn, similar to that at the Lin An site.

The nested-grid model results for 2006 successfully reproduces not only the general features in seasonality of both $\mathrm{O}_{3}$ and $\mathrm{CO}$ at both surface and mountain sites, but also the gra- dients in both species between them. Annual mean levels of both $\mathrm{CO}$ and $\mathrm{O}_{3}$ simulated by the model decrease from south to north, consistent with observations. The summertime trough of both species is well captured by the model. Major deficiencies in model CO simulations include underestimation of $\mathrm{CO}$ at all of the three sites except in the summer. This could be explained by the model's underestimate of $\mathrm{CO}$ emissions in these seasons. For ozone, the model overestimates the minima concentration levels in summer while it underestimates the duration of the summer trough. The discrepancy is probably due to the model's overestimate of ozone in marine boundary layers in summer (Liu et al., 2006) and the model's inability to simulate cloud optical properties associated with the summer monsoon (Y. Wang et al., 2008). The former will lead to a positive bias in the model's estimate of background ozone in summer and the latter will result in a positive bias in the model's estimate of ozone production from local sources. In addition, the fact that the model results (2006) were not sampled for the specific time when the measurements were made could explain part of the discrepancies between model results and observations.

\subsection{Aircraft observations of $\mathrm{O}_{3}$ in springtime outflow from China}

The TRACE-P mission was conducted over the period of March-April 2001 with an objective to characterize the outflow of chemicals from Asia in the spring (Jacob et al., 2003). Two aircraft (DC-8 and P3-B) sampled a wide range of locations over the Western Pacific from bases in Hong Kong and Japan. Wang et al. (2004a, b) reported extensive comparisons of concentrations of $\mathrm{CO}$ and $\mathrm{NO}_{\mathrm{y}}$ species obtained using the nested-grid model with results from the TRACE-P aircraft mission. The model was shown to capture observed spatial variances of $\mathrm{CO}$ and $\mathrm{NO}_{\mathrm{y}}$, but to underestimate their concentrations for the boundary layer north $20^{\circ} \mathrm{N}$ due primarily to an underestimate of Chinese emissions of $\mathrm{CO}$ and $\mathrm{NO}_{\mathrm{x}}$.

Figure 3 compares the mean vertical profile of $\mathrm{O}_{3}$ simulated using the nested-grid model with observations made in TRACE-P for a region north of $20^{\circ} \mathrm{N}$ and west of $150^{\circ} \mathrm{E}$ where the outflow from China was extensively sampled. The model results (black lines) were based on simulations of 2001 meteorology and emissions (Streets et al., 2003) and are 

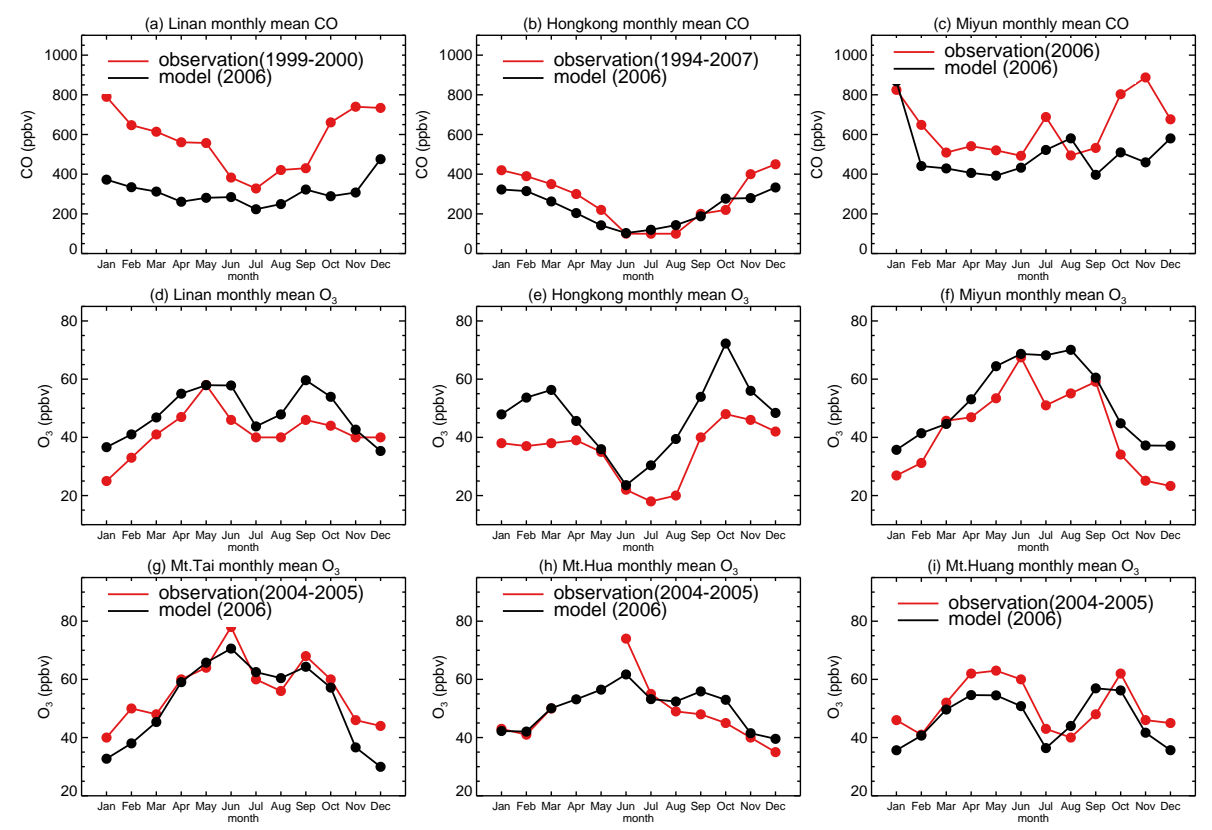

Fig. 2. Monthly mean $\mathrm{O}_{3}$ and $\mathrm{CO}$ at surface and mountain sites in China. The model results for 2006 are shown in black and observations in red. The site locations are shown in Fig. 7.

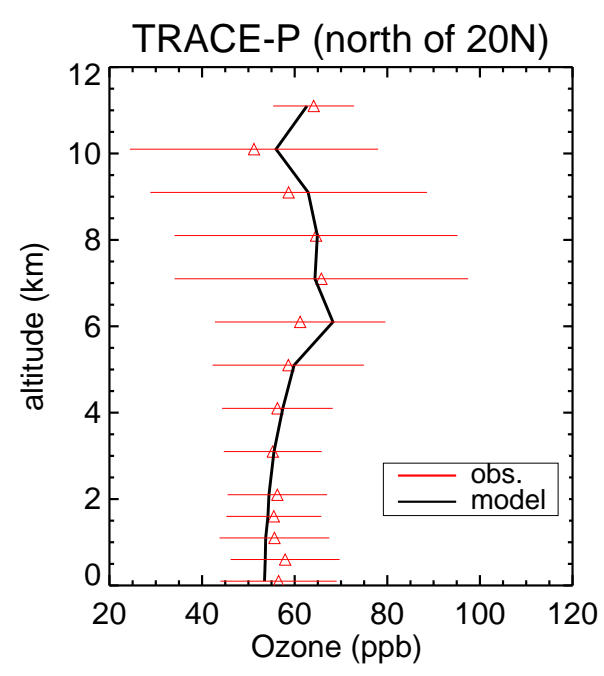

Fig. 3. Ozone profile observed north of $20^{\circ} \mathrm{N}$ during the TRACE$\mathrm{P}$ aircraft mission and model results. Observations are shown in red triangles and the model results as black line. Both model and observations are for the year 2001.

presented in terms of means sampled along the flight tracks and flight times. The observational results are indicated by red dots with red vertical lines denoting means and $1-\sigma$ standard deviations respectively. The nested model satisfactorily captures the observed vertical gradient and reproduces $\mathrm{O}_{3}$ mixing ratios throughout the troposphere, with a minor negative bias of about $5 \%(<3 \mathrm{ppb})$ below $1 \mathrm{~km}$.

\subsection{Seasonality of tropospheric $\mathrm{O}_{3}$ retrieved by TES}

As ground-level ozone is coupled with ozone's abundance in the troposphere, it is necessary to evaluate the model's performance in simulating the seasonality of tropospheric ozone column (TOC) over China. Satellite retrieval of TOC provides a valuable dataset for this purpose as few ozonesonde observations are available over China. Here we adopted TOC products retrieved from Tropospheric Emission Spectrometer (TES) aboard the NASA Aura satellite (Beer, 2006; Wang et al., 2010). TES standard products, global surveys, consists of 16 orbits of nadir vertical profiles every other day and provide 1-3 pieces of information for $\mathrm{CO}$ and ozone in the troposphere (Luo et al., 2007; Nassar et al., 2008). TES version 3 level-2 TOC derived from retrieved profiles during a period of three years (2006-2008) are used. As the present study focuses on regional and seasonal instead of episodic features of ozone over China, monthly mean TES TOC is averaged over two Chinese regions, east and west of China, defined as Chinese domains east and west of $110^{\circ} \mathrm{E}$, respectively. The reason why we separate the data into east/west is because the contribution of Chinese anthropogenic emissions on the tropospheric ozone budget is much larger in the east than the west. There are also distinct differences in topography and landscape between east and west China (cf. Fig. 7).

Figure 4 compares the month to month variation of mean TOC over east (a) and west (b) China simulated by the nested-grd model for 2006 with that retrieved from TES. In the figure, the monthly variability is calculated by subtracting annual mean TOC from monthly mean. TES retrievals 

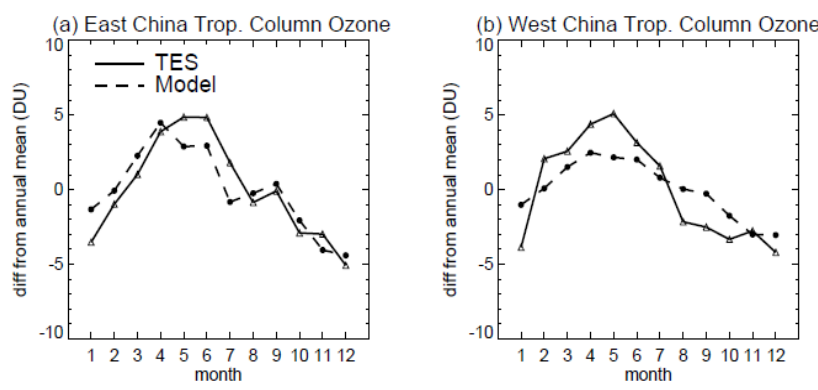

Fig. 4. Month-to-month variations of tropospheric ozone column (TOC) averaged over east (a) and west (b) China retrieved from TES (solid line) and simulated by the model (dash line). Displayed are TES version 3 level-2 TOC retrievals averaged over three years (2006-2008) to improve data representativeness. Model results are for 2006. The monthly variability is shown by subtracting annual mean TOC from the monthly mean.

suggest that TOC over both east and west China has a maximum in late spring/early summer and minimum in winter. The same seasonality has been found over East Asia by Zhao et al. (2010). This general seasonality in TOC is successfully reproduced by the model, but the model's maximum of TOC appears to occur 1-2 months earlier than TES. The seasonal amplitude in TOC is particularly consistent between the model and TES over east China. Over west China, however, the model underestimates the peak in the spring retrieved by TES. TES indicates a secondary peak of TOC in the fall over east China which is well captured by the model.

\subsection{Summary of model evaluation}

Several problems with the model were identified. First, the model has a minor low bias in simulating $\mathrm{O}_{3}$ mixing ratio at the upwind site, Mondy, during maximal inflow seasons (winter and spring). This implies that our model analysis on the trans-Eurasian transport of $\mathrm{O}_{3}$ may be a lower estimate. Second, due to deficiencies in the emission data and the resolution of the model, the model underestimates $\mathrm{CO}$ and likely other ozone precursor emissions over China and tends to underestimate high ozone peaks. Third, the model overestimates the minima ozone levels in summer while underestimates the duration of the summer trough at a few sites due to the model's overestimate of ozone in marine boundary layers in summer and the model's inability to simulate cloud optical properties associated with the summer monsoon.

However, we can see that the model captures the general seasonal pattern in $\mathrm{O}_{3}$ and $\mathrm{CO}$ at the surface for locations upwind, downwind, and within China. The latitudinal gradient of both species inside China is well reproduced by the model. The evaluation against observations from the TRACE-P aircraft mission and TES satellite instruments lends confidence to the model's ability in simulating $\mathrm{O}_{3}$ above the boundary layer. Therefore, we do not expect the model biases to change the main findings of the present study on the regionally- and monthly-averaged, general seasonality of surface ozone over China.

\section{Surface ozone by source category}

In contrast to the pattern observed typically in North America and Europe (maxima in summer), a common feature of surface ozone shown in Fig. 2 is the relatively low $\mathrm{O}_{3}$ levels in the summer months (July-August) which is referred to as the summertime trough of surface ozone over eastern China. For simplicity, the magnitude of the summertime trough is defined as the difference between the summertime minimum and the preceding peak level of ozone. For example, the summertime trough observed at Lin An is of 15 ppbv (Fig. 2d), obtained by the difference between May (peak month) and July (summertime minimum). As shown in Fig. 2, the starting month, duration, and the magnitude of the trough differs by latitude and region. The summertime trough is the focus of model investigation in the present study.

With confidence established by the previous section to the model's ability in simulating key features of ozone observed over China, we apply model sensitivity analyses introduced in Sect. 2 to quantify the contributions from background and domestic anthropogenic emissions on the spatial and seasonal patterns of surface ozone over China. The longrange transport of $\mathrm{NO}_{\mathrm{x}}$ will have a relatively large impact on $\mathrm{OH}$ radicals and thus affect the abundance and distribution of atmospheric $\mathrm{CH}_{4}$, which partly offsets the short-term increase in $\mathrm{O}_{3}$ due to $\mathrm{NO}_{\mathrm{x}}$ emission increases (Derwent et al., 2001; Wild et al., 2001). As our model simulations focus on periods of 1-2 $\mathrm{yr}$ (including spin-up), we do not account for the long-term effect of $\mathrm{NO}_{\mathrm{x}}$ on ozone via $\mathrm{CH}_{4}$ due to the long response time of $\mathrm{CH}_{4}(\sim 12 \mathrm{yr})$. The Hemispheric Transport of Air Pollutants (HTAP) study (TF HTAP, 2010, www.htap.org) suggests that for simulations in which anthropogenic emissions of ozone precursors $\left(\mathrm{NO}_{\mathrm{x}}, \mathrm{NMVOC}\right.$ and $\mathrm{CO}$ ) are reduced simultaneously as in this study, the longterm feedback of $\mathrm{NO}_{\mathrm{x}}$ on $\mathrm{O}_{3}$ through $\mathrm{CH}_{4}$ is less than $3 \%$ for all months and regions and therefore could be negligible.

\subsection{Mean background}

Table 2 summarizes mean and spatial variability (defined as the standard deviation of all model grids falling within the region, including only the land areas) of surface ozone averaged over China as a whole by season. Annual mean TBO over China is $44.1 \mathrm{ppbv}$, with maximum in spring (50.7 ppbv) and minimum in summer (40.9 ppbv), accounting for $93 \%$ and $81 \%$ of total surface ozone in these seasons respectively. The seasonality of TBO is consistent with that of long-range transport to East Asia, Europe and North America suggested by previous studies (Fiore et al., 2003; Auvray and Bey, 2005; Wild et al., 2004; TF HTAP, 2010, www.htap.org). As the present study perturbs only Chinese anthropogenic emissions, mean background ozone derived over China is 
Table 2. Surface ozone and its decomposition ${ }^{a}$ averaged over China by season. Results are presented as mean \pm spatial variability (unit: ppbv).

\begin{tabular}{lrrrrr}
\hline Season & $\begin{array}{r}\text { total } \\
\text { ozone (TO) }\end{array}$ & $\begin{array}{r}\text { Total } \\
\text { background (TBO) }\end{array}$ & $\begin{array}{r}\text { Natural } \\
\text { background (NBO) }\end{array}$ & $\begin{array}{r}\text { Pollution } \\
\text { background (PBO) }\end{array}$ & $\begin{array}{r}\text { China } \\
\text { Pollution (CPO) }\end{array}$ \\
\hline Winter (DJF) & $44.4 \pm 5.7$ & $43 \pm 5.9$ & $30.2 \pm 4.7$ & $12.8 \pm 1.5$ & $1.4 \pm 3.5$ \\
Spring(MAM) & $54.7 \pm 5.3$ & $50.7 \pm 8.6$ & $35.9 \pm 7.4$ & $14.8 \pm 2.2$ & $4 \pm 5.4$ \\
Summer(JJA) & $50.8 \pm 10.2$ & $40.9 \pm 12.9$ & $30.9 \pm 10.4$ & $10 \pm 4$ & $9.9 \pm 9.2$ \\
Fall (SON) & $48.3 \pm 6.2$ & $41.7 \pm 9$ & $29 \pm 6.8$ & $12.7 \pm 2.6$ & $6.6 \pm 7.5$ \\
Annual mean & $49.5 \pm 5.2$ & $44.1 \pm 8.5$ & $31.5 \pm 6.7$ & $12.6 \pm 2.3$ & $5.4 \pm 5$ \\
\hline
\end{tabular}

a Please refer to Sect. 2 of the text for the decomposition.

higher than background ozone over East Asia suggested by the HTAP study that reduced all East Asian anthropogenic emissions. Similarly, H. Wang et al. (2008) found higher background over the US when Canadian and Mexican emissions were included as background. Another difference between this study and the HTAP study (Fiore et al., 2009) is that the HTAP simulations did not zero out emissions, but applied 20\% emission decreases. Wu et al. (2009) found that the perturbation from a $100 \% \mathrm{NO}_{\mathrm{x}}$ emission reduction always resulted in ozone responses greater than 5 times the $20 \% \mathrm{NO}_{\mathrm{x}}$ emission reductions in any season and any sourcereceptor pair and this nonlinearity was significant except in summer. This suggests that the influence of intercontinental transport on ozone background over China estimated in this study using zero-out simulations would be higher than the HTAP study.

In all seasons, at least $70 \%$ of TBO is of natural origin. Mean NBO ranges from $29.0 \mathrm{ppbv}$ in the fall to $35.9 \mathrm{ppbv}$ in the spring, with an annual mean of $31.5 \mathrm{ppbv}$. The peak of NBO in the spring can be attributed to enhanced stratospheretroposphere exchange (STE) activities in this season over North Hemisphere. Mean PBO ranges from $10.0 \mathrm{ppbv}$ in the summer to $14.8 \mathrm{ppbv}$ in the spring, with an annual mean of $12.6 \mathrm{ppbv}$. The spatial variability of background ozone is largest in the summer (cf. Fig. 6b), as background ozone arising from biogenic emissions of $\mathrm{NO}_{\mathrm{x}}$ and VOCs which peak in the summer is not necessarily collocated with stratospheric ozone or pollution background. Mean CPO ranges from $9.9 \mathrm{ppbv}$ in the summer to only $1.4 \mathrm{ppbv}$ in winter. For all of China, CPO contributes an average of about $20 \%$ of $\mathrm{TO}$ in the summer. However, the spatial variability in CPO reaches up to $100 \%$ compared with only $20 \%$ of variability in TO, as CPO accounts for much larger fractions over regions of large local emissions (cf. Figs. 5e and 6e). The spatial variability in CPO exceeds $100 \%$ in the winter, as the model indicates negative $\mathrm{CPO}$ for northern regions in this season. With limited production of $\mathrm{OH}$ radicals in the winter at higher latitudes, enhancement in anthropogenic $\mathrm{NO}_{\mathrm{x}}$ emissions will lead to ozone destruction through the so-called titration mechanism $\left(\mathrm{NO}+\mathrm{O}_{3} \rightarrow \mathrm{NO}_{2}+\mathrm{O}_{2}\right)$.

\subsection{Spatial distributions}

Spatial distributions of surface ozone and its different components for annual mean and summertime (JJA) conditions are presented in Figs. 5 and 6 respectively. Annual mean ozone concentrations (Fig. 5a) are relatively high ( $>50 \mathrm{ppb}$ ) over a zonal band extending from the elevated Tibetan Plateau in the west to central-east China (between $25^{\circ}$ and $\left.40^{\circ} \mathrm{N}\right)$. The high- $\mathrm{O}_{3}$ band expands northward and eastward in summer (Fig. 6a), with highest concentrations (>60 ppb) shifted to NCP where anthropogenic emissions are large. TBO is highest over western China (west of $100^{\circ} \mathrm{E}$ ), accounting for about $90 \%$ of total surface ozone abundance both annually and in summer (Figs. 5b and 6b). TBO shows a distinct spatial gradient over China, decreasing from northwest to southeast. This gradient of TBO is largest in the summer (Fig. 6b), decreasing from $55 \mathrm{ppb}$ over west China to less than 30 ppbv over southeast China. The NBO (Figs. $5 \mathrm{c}$ and 6c) resembles the spatial distribution of TBO, as NBO is the dominant component of TBO. In contrast, the CPO is highest over eastern China where anthropogenic emissions are large (Figs. 5e and 6e).

The abundance of PBO at the surface (Figs. $5 \mathrm{~d}$ and $6 \mathrm{~d}$ ) is much lower than NBO. The spatial distribution of PBO is different than TBO or NBO. It is relatively high over the coastal zones and southwest China because of the region's proximity to pollutions from neighboring countries/regions such as Japan, Korea, Southeast Asia and South Asia. PBO over China is on average 3 ppbv lower in the summer compared with annual mean, reflecting the influence of marine air inflow in summer. We will examine the factors resulting in the seasonal changes in the next Section.

Figure 7 presents the topography of China, illustrating the contrast in elevation between west and east China. Tibetan Plateau in the southwest has a mean elevation of over $3000 \mathrm{~m}$, while Northwestern China $\left(35-40^{\circ} \mathrm{N}\right.$, west of $\left.110^{\circ} \mathrm{E}\right)$ has a mean elevation of about $2000 \mathrm{~m}$. In contrast, the plain regions in central east and the hilly regions in southeast are of elevations lower than $500 \mathrm{~m}$ and $1000 \mathrm{~m}$ respectively. There are two topography-related factors responsible for the relatively high NBO and thus TBO over west China. First, it 

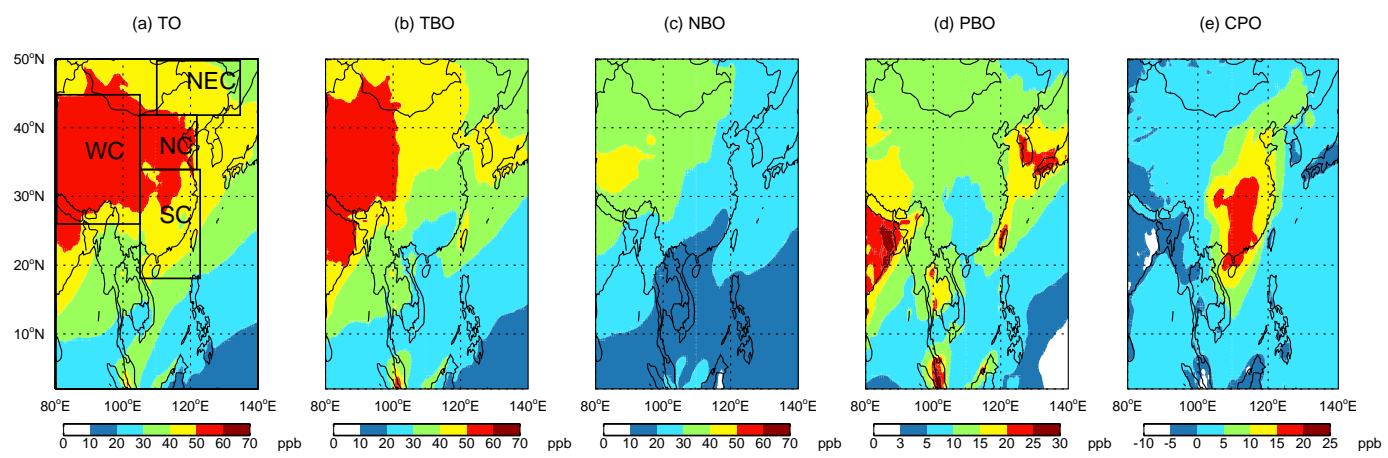

Fig. 5. Annual mean spatial distribution of surface ozone over China. The figure shows the total surface ozone (TO) (a), total background ozone (TBO) (b), natural background ozone (NBO) (c), pollution background ozone (PBO) (d), and China pollution ozone (CPO) (e). Note that the color scales for (d) and (e) are different from those of (a-c). The black lines in (a) show the definition of Chinese regions (WC, $\mathrm{NEC}, \mathrm{NC}$, and SC).
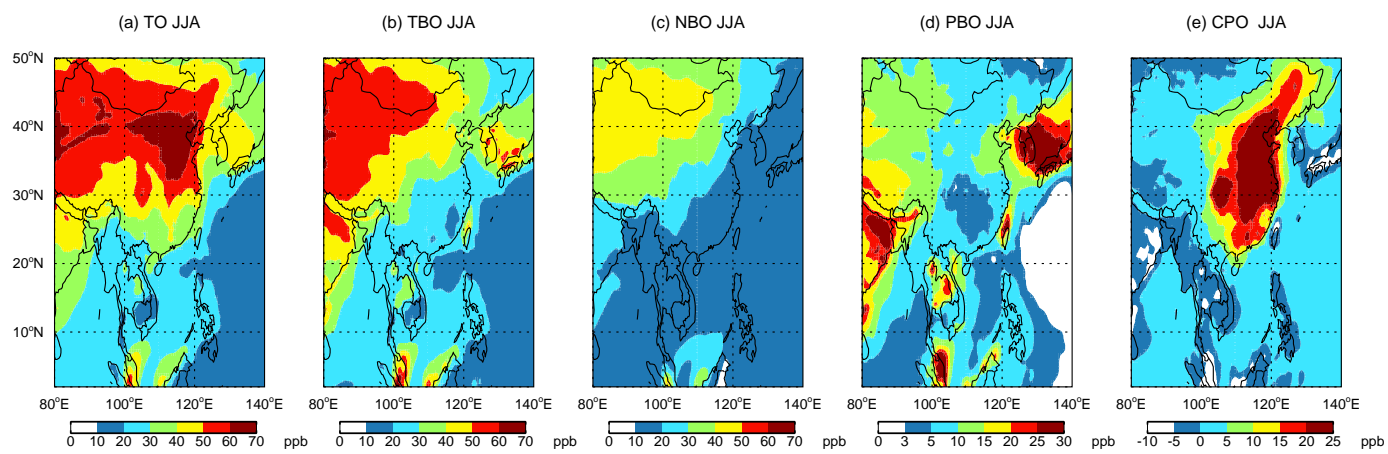

Fig. 6. Same as in Fig. 5, but for summer (June, July and August) mean value.

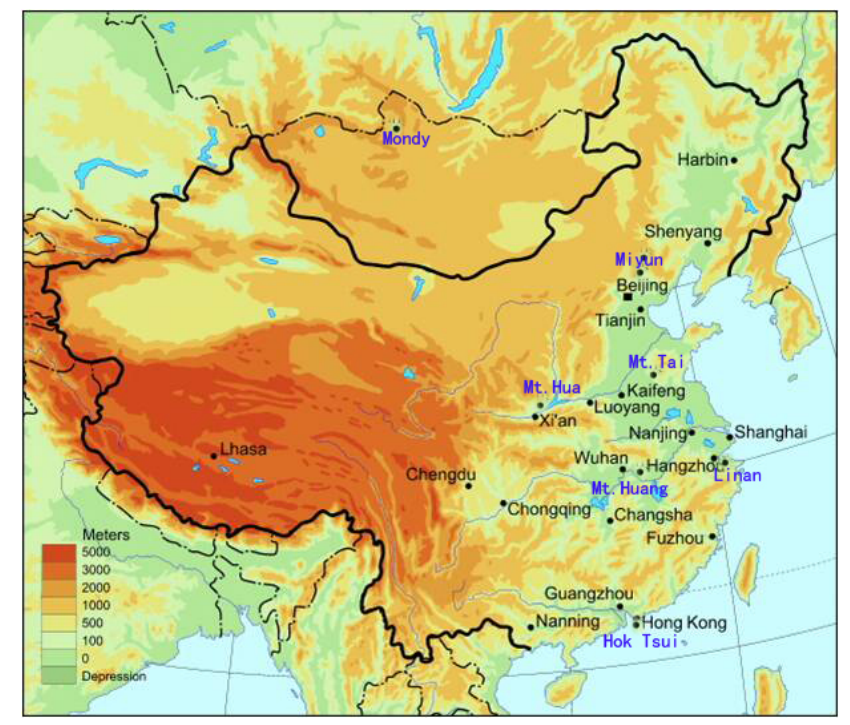

Fig. 7. Topography (meters) of China. The locations of the observation sites shown in Figs. 1 and 2 are indicated as blue dots. Some selected big cities (black dots) are also shown. can be attributed to stratospheric influences because of the high altitude. This is supported by the tagged ozone simulation in Sect. 5. Second, it can be explained by spatial variability in ozone lifetime. The mean lifetime of ozone in the mixed layer against dry deposition and chemical losses over China in the summer is presented in Fig. 8. The chemical loss rates are calculated for the extended odd oxygen family $\left(\mathrm{O}_{\mathrm{x}}=\mathrm{O}_{3}+\mathrm{O}+\mathrm{NO}_{2}+2 \mathrm{NO}_{3}+\mathrm{PANs}+\mathrm{HNO}_{4}+\right.$ $\mathrm{HNO}_{3}+3 \mathrm{~N}_{2} \mathrm{O}_{5}$ ) as in Fiore et al. (2002). $\mathrm{O}_{\mathrm{x}}$ is hereafter referred to as $\mathrm{O}_{3}$ since $\mathrm{O}_{3}$ usually accounts for over $95 \%$ of $\mathrm{O}_{\mathrm{x}}$. The mean lifetime of $\mathrm{O}_{3}$ in the mixed layer is greater than 5 days over the arid Loess Plateau in northwest China and over parts of the Tibetan Plateau. The lifetime in East China is typically less than 2 days, reflecting shallow mixing depth, faster deposition velocities, and more active chemical loss due to higher emissions of biogenic hydrocarbons and higher humidity. The strong northwest-to-southeast gradient in the lifetime of ozone is significant also in other seasons, resulting in the reduced concentrations of TBO and NBO over eastern China. The gradient in ozone lifetime coincides with the spatial gradient in topography and other meteorological/geophysical parameters (such as precipitation, vegetation coverage, etc.). Our analysis is consistent with the study of 


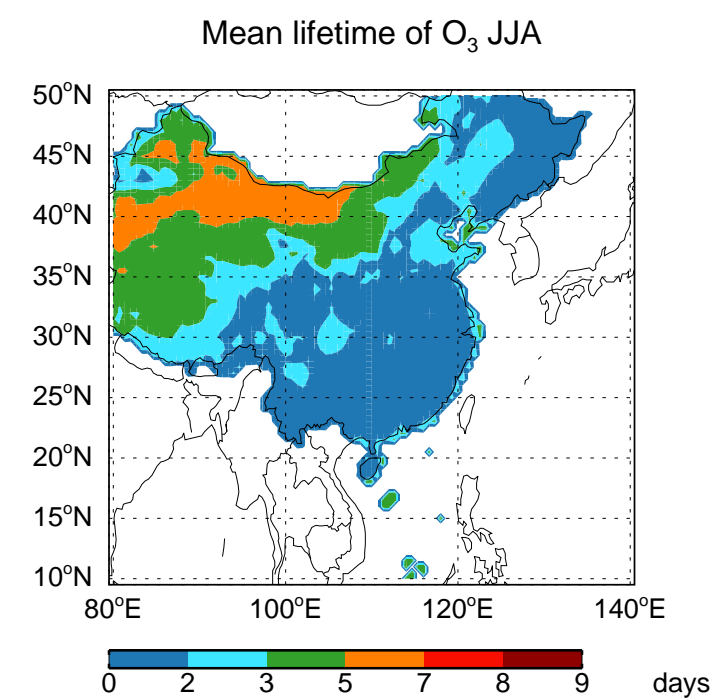

Fig. 8. Mean lifetime of ozone in the summer (JJA).

Fiore et al. (2002) in which they found that the background of $\mathrm{O}_{3}$ was generally higher in the western United States than in the eastern US because of the higher lifetime of $\mathrm{O}_{3}$ in the west with the arid climate.

\subsection{Seasonality}

Careful analyses of the results from the standard simulation suggest that it is not appropriate to generalize one seasonal pattern for surface ozone that can fit for situations across all parts of China. Therefore, we focus our analysis for four different regions in China: West China (WC; defined as 25$45^{\circ} \mathrm{N}$, west of $110^{\circ} \mathrm{E}$ ), Northeastern China (NEC; $42-50^{\circ} \mathrm{N}$, $\left.120-135^{\circ} \mathrm{E}\right)$, North China $\left(\mathrm{NC} ; 34-42^{\circ} \mathrm{N}, 110-120^{\circ} \mathrm{E}\right)$, and South China (SC; region between $22-34^{\circ} \mathrm{N}, 110-120^{\circ} \mathrm{E}$ ). The definition of these regions, illustrated in Fig. 5a, partly follows the conventional division of geographical regions in China and partly reflects the spatial distribution of different ozone components shown in Figs. 5-6. West China refers to the region west of $110^{\circ} \mathrm{E}$ with high elevation and arid climate. Natural ozone background is relatively high over WC. South China includes the subtropical middle and lower Yangtze Plains and southeast coastal mountains and hills, while North China covers temperate North China Plain. SC and $\mathrm{NC}$ are conventionally divided by the Yangtze River. Both SC and $\mathrm{NC}$ are located east of $110^{\circ} \mathrm{E}$ and they in combination are referred to as eastern China. Both SC and NC have larger population, higher gross domestic production, and consequently larger anthropogenic pollutant emissions than WC or NEC. As a result, the CPO is highest over NC and SC. Northeast China is at higher latitude with humid temperate climate, and is most easily influenced by European pollutions due to its latitude.
Figure 9a-d summarizes the month-to-month variations of mean surface ozone (red circles) averaged over the four Chinese regions. Over WC, TO peaks in spring and reaches a minimum in summer. Over NEC, it peaks in spring and has its minimum in winter. $\mathrm{TO}$ over $\mathrm{NC}$ reaches a maximum in June, only to decrease significantly in July (cf., Fig. 2f-h). This is consistent with the seasonality of ozone observed at Miyun site(Y. Wang et al., 2008, 2010b) and Mt. Tai (Li et al., 2007). TO over SC has a distinct double-hump shape, with peaks in the fall and spring and minimum in summer, similar to observations at the Lin An and Hong Kong sites. Annual mean surface ozone is highest over NC, followed in order by WC, SC, and NEC. Mean springtime ozone is highest over WC, while in summertime it is highest over NC and lowest over SC.

Seasonality of individual ozone components displayed in Fig. 9 provides useful evidence for identifying important factors controlling the seasonal variability of surface ozone over different regions. NBO show distinct peaks in the spring over all four regions, reflecting the influence of STE on natural ozone background over the northern middle latitudes (cf., right panels in Fig. 10). NBO is highest over WC and lowest over SC. It is the largest component of TO over WC and NEC all year round. The seasonal amplitude of NBO is about $10 \mathrm{ppbv}$ over the four regions. PBO shows distinct troughs in summer over all four regions. This can be explained in part by the decrease in the lifetime of ozone and its precursors in summer (thus unfavorable for long-range transport) and in part by summer monsoonal circulation which brings marine air masses with lower ozone to China. The transport issue will be investigated in Sect. 5 using the tagged ozone simulation. Monthly mean PBO ranges from 5 to $17 \mathrm{ppb}$ depending on region and season. The lowest $\mathrm{PBO}$ is over SC in the summer. PBO peaks in spring over all regions due to longer $\mathrm{O}_{3}$ lifetime (Wang et al., 1998b, c) and larger influx of European pollution (Wild et al., 2004). As the combination of NBO and PBO, TBO has a maximum in spring over all four regions. In WC, the seasonality of TO is determined by that of TBO. The spring peak of TO over NEC and SC is attributable also to TBO.

In contrast to the spring peak of hemispheric pollution background (PBO), ozone originated from Chinese pollutions (CPO) peaks in the summer and fall. This reflects stronger in situ production of ozone from local/regional precursor emissions under warmer temperature and stronger solar radiation prevailing in these seasons. CPO over WC is nearly zero in the winter and spring. It increases to a mean level of $5 \mathrm{ppbv}$ from July to October, still lower than either natural background or anthropogenic background ozone in these months as local anthropogenic sources are minimal over WC and the contribution of CPO from the dense emission regions in the east to $\mathrm{WC}$ is estimated to be less than $5 \mathrm{ppbv}$ at the surface according to the tagged ozone simulation in Sect. 5 (cf. Fig. 10). Over NEC, CPO has higher concentrations extending from spring to autumn. It ranges from 

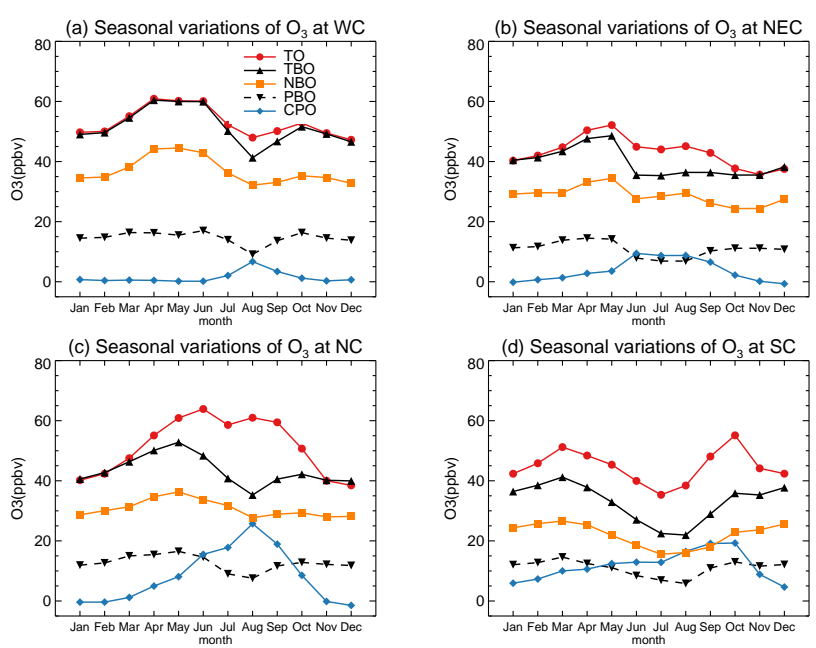

Fig. 9. Monthly variations of mean surface ozone (TO, red circles), total background ozone (TBO, solid line with black upward triangles), natural background ozone (NBO, orange squares), pollution background ozone (PBO, dotted line with black downward triangles), and China pollution ozone (CPO, blue diamond) for different Chinese regions. The unit is ppbv. The regions are defined in Fig. 5a.

-2 ppbv in December/January to 15 ppbv in June. The negative value indicates limited production of $\mathrm{OH}$ radicals in this region in the winter to oxidize anthropogenic $\mathrm{NO}_{\mathrm{x}}$ emissions leading to net production of ozone. Instead, enhancement in anthropogenic $\mathrm{NO}_{\mathrm{x}}$ emissions will lead to ozone destruction through the titration reaction. Because of CPO's contribution, ozone minimum over NEC occurs in the winter instead of summer. The contribution of CPO to total ozone is much larger over $\mathrm{NC}$ and SC where anthropogenic emissions are large. Annual mean CPO over NC and SC is 8 and $11 \mathrm{ppbv}$ respectively. Monthly mean $\mathrm{CPO}$ reaches up to $25 \mathrm{ppbv}$ over NC in August and 20 ppbv over SC in September. Nevertheless, TBO still contributes for more than $50 \%$ of total surface ozone over NC and SC in all seasons.

$\mathrm{NC}$ and SC have dense population and higher level of economic development, so we discuss the seasonality of CPO and TBO over these two regions in more detail. Over NC (Fig. 9c), monthly mean CPO exceeds 15 ppbv from June to September, with a maximum of $25 \mathrm{ppbv}$ in August. Although TBO decreases by 5 ppbv from May to June, CPO increases by about $10 \mathrm{ppbv}$ during the same period, leading to a maximum of TO (the sum of TBO and CPO) in June. TBO further decreases by 10 ppbv from June to July, while CPO increases by only 3 ppbv suggesting slower net in situ production of ozone in July compared with June. As a result, TO shows a decrease from June to July. From July to August, CPO increases by another 10 ppbv offsetting the $5 \mathrm{ppbv}$ decrease in TBO, leading to a secondary peak of TO in August. Y. Wang et al. (2008) attributed the decrease in surface $\mathrm{O}_{3}$ from June to July at the Miyun site to increases in
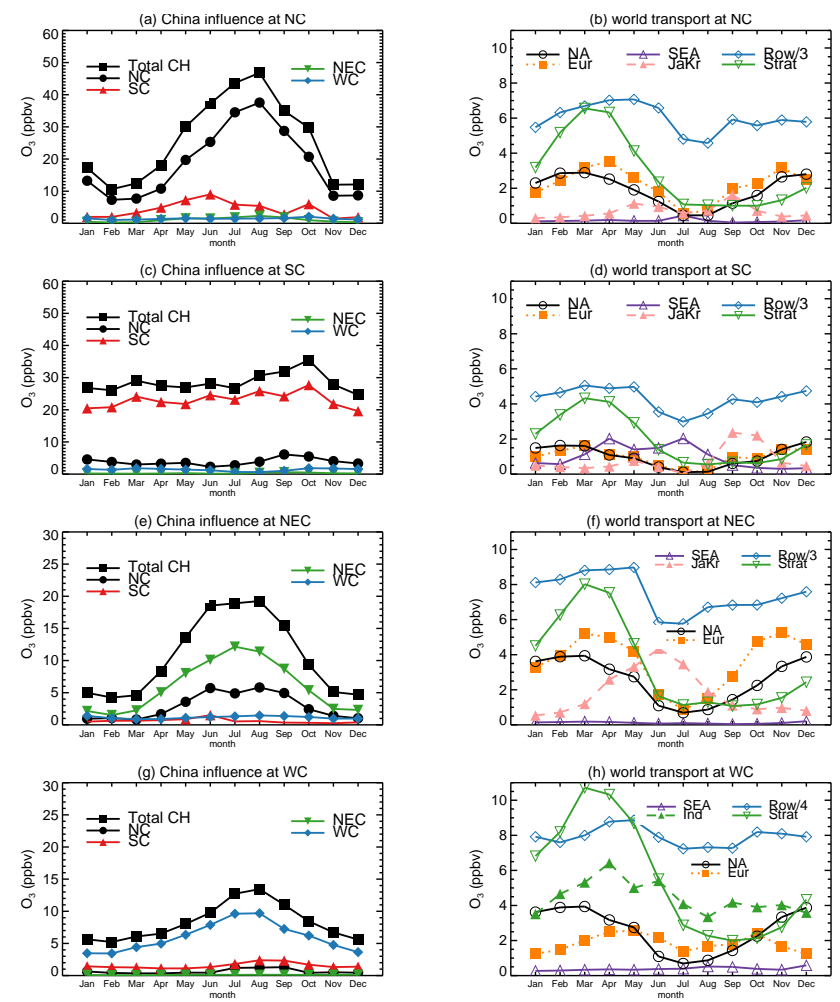

Fig. 10. Monthly mean mixing ratios of tagged ozone tracers over the four Chinese regions. Chinese tracers are shown in the left panels (a, c, e, $\mathbf{g})$ and non-Chinese tracers in the right panels $(\mathbf{b}, \mathbf{d}, \mathbf{f}$, h). For simplicity, tracers with little seasonality or minimal impact on the receptor regions are not displayed in the figure. Note the different scale of the $y$-axis between the left and right panels.

monsoonal rainfall and cloudiness in July as optically-thick clouds suppress photochemical production of $\mathrm{O}_{3}$. The JuneJuly variation in CPO identified here for NC as a whole may be explained by the same mechanism since July is the month when monsoonal rainfall reaches North China region.

Over SC (Fig. 9d), CPO peaks in the fall instead of summer, leading to the maximum of TO in the fall. Summer monsoon season has a longer duration over SC with heavy rainfall and extensive clouds. Although ozone production can be significant in days when it is clear, the overall meteorology in summer is less favorable for in situ production and accumulation of ozone than in the fall when it is generally warm and sunny with little precipitation. The increase in CPO from spring to summer is only 5 ppbv, far from offsetting a large decrease of $20 \mathrm{ppbv}$ in TBO during the same period. Therefore, total surface ozone still exhibits a summer minimal over SC, similar to TBO. Mean CPO is positive over $\mathrm{SC}$ in the winter, suggesting enough production of $\mathrm{OH}$ radical to oxidize anthropogenic $\mathrm{NO}_{\mathrm{x}}$ emissions leading to net production of ozone. This is because at lower latitude, SC has plenty of solar radiation even in winter. 


\section{Surface ozone by source region}

The sensitivity simulation discussed in the previous section is an effective method to relate quantitatively surface ozone components to different source types of precursor emissions: natural versus anthropogenic, domestic pollution versus outside China. Due to computational constraints, however, the number of sensitivity simulations that can be conducted effectively is limited. In this section, we apply the tagging method to evaluate contributions on surface ozone by source region, as done by Wang et al. (1998c) and Fiore et al. (2002). 3 -D fields of daily mean production and loss frequencies of the odd oxygen family $\left(\mathrm{O}_{\mathrm{x}}\right.$; cf. Sect. 4.2) archived from our standard simulation are used to drive an off-line ozone simulation, in which ozone in the model is tagged by region of production. Total ozone is the sum of individual tagged tracers produced in different regions. Each tracer is subjected to the same chemical loss and dry deposition frequencies as the total $\mathrm{O}_{3}$, but is produced only within its specific source region. This approach allows surface ozone over China to be decomposed into components produced from different regions, but does not track the locations of the precursor emissions which give rise to the ozone production. We defined the following 10 source regions: four Chinese regions as described in Sect. 4.3, Europe (EU; defined as north of $38^{\circ} \mathrm{N}$, $15^{\circ} \mathrm{W}-55^{\circ} \mathrm{E}$ ), North America (NA; $20^{\circ} \mathrm{N}-75^{\circ} \mathrm{N}, 127^{\circ} \mathrm{W}-$ $65^{\circ} \mathrm{W}$ ), Southeast Asia (SEA; $10^{\circ} \mathrm{S}-22^{\circ} \mathrm{N}, 90^{\circ} \mathrm{E}-110^{\circ} \mathrm{E}$, and $10^{\circ} \mathrm{S}-18^{\circ} \mathrm{N}, 110-130^{\circ} \mathrm{E}$ ), India (IND; $6^{\circ} \mathrm{N}-38^{\circ} \mathrm{N}, 60$ $\left.{ }^{\circ} \mathrm{E}-90^{\circ} \mathrm{E}\right)$, Japan and Korea (JaKr; $30^{\circ} \mathrm{N}-54^{\circ} \mathrm{N}, 125^{\circ} \mathrm{E}-$ $150^{\circ} \mathrm{E}$ ), and the rest of world (ROW). Except for ROW, each source region extends from the surface up to $2.5 \mathrm{~km}$ altitude or about $750 \mathrm{hPa}$, representing only the PBL. Ozone produced above $2.5 \mathrm{~km}$ is counted into ROW. Stratospheric injection is treated as a separate tracer. In what follows, a tagged region is referred to as the source region of its own tagged tracer, while the four Chinese regions are the receptor regions of interest in this paper. The sum of $\mathrm{O}_{3}$ from all source regions is within a few percent of the total $\mathrm{O}_{3}$ in the standard full chemistry simulation.

Figure 10 presents monthly mean concentrations of tagged $\mathrm{O}_{3}$ tracers averaged over the four Chinese regions. We first discuss the Chinese tracers displayed on the left panels. The sum of tagged Chinese tracers (total $\mathrm{CH} \mathrm{O}_{3}$ for short), representing total ozone produced within the Chinese PBL, is shown as a filled black square. We should note here that total $\mathrm{CH} \mathrm{O}_{3}$ is larger than $\mathrm{CPO}$ derived from the sensitivity simulation (cf. Fig. 9) although they have very similar monthto-month variability. This is because the former accounts for ozone produced in PBL above China from all sources of precursors, either natural or anthropogenic or those originated from outside China, as long as they result in ozone production within the receptor region. Nagashima et al. (2010), using the tagged tracer model analysis, suggests that $40 \%-$ $50 \%$ of surface ozone over NC and SC is produced domestically within the PBL of China in spring and the domestic contributions increase in summer. The results in Fig. 10 indicate the same seasonal variation in the contribution of total $\mathrm{CH} \mathrm{O}_{3}$ to surface ozone over $\mathrm{NC}$ and SC. Total $\mathrm{CH} \mathrm{O} 3$ accounts for about $40-45 \%$ of surface ozone over NC and SC in spring and the fraction increases to about $75 \%$ in summer. The increasing contribution of total $\mathrm{CH} \mathrm{O}_{3}$ from spring to summer is in contrast to and therefore not the cause of the summertime trough of surface ozone over eastern China. From Fig. 10, one can see that ozone produced within the source region makes the biggest contribution to total surface ozone for the same region. For example, tagged $\mathrm{NC} \mathrm{O}_{3}$ (i.e., ozone produced over North China PBL) ranges from $7 \mathrm{ppbv}$ in the winter to $38 \mathrm{ppbv}$ in the summer over NC (Fig. 10a), compared with only $6 \mathrm{ppbv}$ in the fall over the receptor region of SC (Fig. 10c). Chinese $\mathrm{O}_{3}$ all peak in the summer over their source regions, with the only exception of $\mathrm{SC} \mathrm{O}_{3}$ which peaks in the fall over SC for reasons discussed before.

The seasonality of Chinese $\mathrm{O}_{3}$ over the receptor regions indicates transport pathways of ozone within China. $\mathrm{NC} \mathrm{O}_{3}$ reaches a peak level of 6 ppbv over SC in the fall, while a similar maximum level of $\mathrm{SC} \mathrm{O}_{3}$ is found over $\mathrm{NC}$ in late spring and early summer (May-June). This suggests that the fall season is the period of maximum export of ozone from $\mathrm{NC}$ to SC, while May to June is the period of largest export of ozone from SC to NC. These transport routes can be explained by the prevailing southwesterly in the summer and northwesterly in the fall associated with the monsoonal circulation. This cross-regional transport of ozone between NC and SC provides an additional mechanism to explain why surface ozone peaks in June and in the fall, respectively, over $\mathrm{NC}$ and SC. Compared with $\mathrm{NC}$ or $\mathrm{SC} \mathrm{O}_{3}$, WC and $\mathrm{NEC} \mathrm{O}_{3}$ make significant contributions only at their source regions (Fig. 10e and g). In the summer when the prevailing wind is southwesterly, $\mathrm{NC} \mathrm{O}_{3}$ has its maximum influence over NEC, while $\mathrm{SC}_{3}$ reaches its peak over WC. Peak level of NC and $\mathrm{SC} \mathrm{O}_{3}$ is about $5.8 \mathrm{ppbv}$ and $2.4 \mathrm{ppbv}$ over NEC and WC respectively.

Monthly mean mixing ratios of selective non-Chinese tracers are shown on the right panels of Fig. 10. As these tracers represent the contribution of ozone produced outside Chinese PBL, their month-to-month variations shed some light on the impact of different source regions on the seasonality of background ozone discussed in Sect. 4.3. $\mathrm{ROW} \mathrm{O}_{3}$ has the largest influence over China as it includes the world-wide production of ozone above the PBL. ROW $\mathrm{O}_{3}$ exhibits a summertime trough over all Chinese regions. The abundance of $\mathrm{EU}$ $\mathrm{O}_{3}$ decreases from north to south over China, with largest annual mean influence of $3.6 \mathrm{ppbv}$ over NEC and lowest of 1.2 ppbv over $\mathrm{SC}$. NA $\mathrm{O}_{3}$ exhibits a similar spatial pattern as $\mathrm{EU} \mathrm{O}_{3}$ but of lower mixing ratio, decreasing from an annual mean level of $2.6 \mathrm{ppbv}$ over NEC to that of $1.2 \mathrm{ppbv}$ over SC. $\mathrm{EU} \mathrm{O}_{3}$ tends to peak in the spring while $\mathrm{NA} \mathrm{O}_{3}$ often peaks in the winter, while both of them have a minimum in the summer. Fiore et al. (2009) and the MICS-Asia study (Holloway et al., 2008) indicated the same seasonality 
and comparable magnitude of $\mathrm{EU}$ and $\mathrm{NA} \mathrm{O}_{3}$ at the surface over East Asia. The HTAP study (www.htap.org) suggests that the long-range transport of ozone from NA and EU to East Asia (EA) has a minimum in summer and estimated that the full annual-mean contribution of NA and EU to EA is $1.1 \mathrm{ppbv}$ and $1.2 \mathrm{ppbv}$ respectively (TF HTAP, 2010). The annual-mean magnitude of the NA and EU tracer over eastern China is $1.2 \mathrm{ppv}$ and $1.5 \mathrm{ppbv}$ respectively (Fig. 10b and d), consistent with the HTAP study. Despite of the apparent consistency, we caution here that a direct comparison is not so meaningful because the HTAP study gives the mean impact averaged over East Asia as a whole whereas our study looks exclusively at China. Compared with NA and EU, $\mathrm{SEA} \mathrm{O}_{3}$ has a smaller contribution of less than $1 \mathrm{ppbv}$ all year round over NEC, NC, and WC. The exception is that SEA $\mathrm{O}_{3}$ reaches $1.4-2.1 \mathrm{ppbv}$ from April to July over SC, larger than NA or $\mathrm{EU} \mathrm{O}_{3}$. This is due to the shorter transport route from SEA to SC during this period under the prevailing southwesterly winds. The springtime enhancement of SEA $\mathrm{O}_{3}$ is resulted from biomass burning that peaks in this season over Southeast Asia (Duncan et al., 2003).

The biggest influence of $\mathrm{JaKr} \mathrm{O}_{3}$ is over NEC, reaching 2-4.5 ppbv from April to August with an annual mean of 2 ppbv and a peak in June. It also has a significant contribution over NC and SC in the fall reaching up to 2 ppbv over both regions. $\mathrm{JaKr} \mathrm{O}_{3}$ exerts the largest influence over NEC in the summer and over NC/SC in the fall, as a result of the change in prevailing wind directions. Indian $\mathrm{O}_{3}$ makes large contributions over WC all year round, with an annual mean of $4.5 \mathrm{ppbv}$ exceeding those from EU or NA. It peaks in the spring, again consistent with prevailing wind directions.

A common feature for all four Chinese receptor regions is that ozone exported from NA, EU and ROW reaches a minimum in the summer. In contrast, ozone exported from SEA exhibits a maximum in the summer over eastern China (NC and SC), with negligible influence over the inland regions (i.e., $\mathrm{WC}$ and NEC). NA and $\mathrm{EU} \mathrm{O}_{3}$ in combination result in a decrease of 4-8 ppbv from spring to summer over different regions in China, more than offsetting an increase of less than 2 ppb resulting from SEA $\mathrm{O}_{3}$ during the same period. $\mathrm{O}_{3}$ from $\mathrm{ROW}$ contributes to a further decrease of about $8 \mathrm{ppbv}$ from spring to summer. The contrast in seasonality between the tagged tracers provides clear evidence that it is the seasonal switch in monsoonal wind patterns that plays a significant role in determining the seasonality of background ozone over China. The northwesterly monsoon brings polluted northern continental air masses with higher ozone levels in the spring and fall as represented by $\mathrm{NA}$ and $\mathrm{EU} \mathrm{O}$. It switches to southwesterly in the summer bringing in relatively clean marine air masses from the south. As a result, anthropogenic background ozone shows a distinct summer minimum over all regions of China.

\section{Concluding remarks}

In this study, we use a nested-grid chemical transport model with a horizontal resolution of $0.5^{\circ} \times 0.667^{\circ}$ to quantify contributions of various source types (natural and anthropogenic) and regions (domestic and foreign) to the spatial distribution and seasonality of surface ozone over China. Surface observation, satellite-derived tropospheric ozone column, and nested-grid model all suggests that surface ozone over populated eastern China features a summertime trough. The peak month of surface ozone differs by latitude and region, changing from October in the Pearl River Delta (PRD) to May in the Yangtze River Delta (YRD) and to June in the North China Plain (NCP). With confidence in the model's ability in simulating key features of ozone observed upwind, downwind and over China, we apply model sensitivity analyses to decompose total surface ozone (TO) into contributions from total background ozone (TBO), natural background (NBO), pollution background ( $\mathrm{PBO}$ ), and the enhancement from Chinese anthropogenic pollutants (CPO). We found that annual mean background ozone over China shows a spatial gradient from $55 \mathrm{ppbv}$ in the northwest to $20 \mathrm{ppbv}$ in the southeast, corresponding with changes in topography and ozone lifetime. NBO resembles the spatial distribution of TBO, as NBO is the dominant component of TBO. PBO (annual mean of $12.6 \mathrm{ppbv}$ ) shows a minimum in the summer and maximum in the spring. It is relatively high over the coastal zones and southwest China because of the proximity to pollutions from neighboring countries/regions. In contrast to background ozone, the CPO is highest over eastern China where anthropogenic emissions are large. On the monthly-mean basis, CPO has a peak of 20-25 ppbv in June north of the Yangtze River and in October south of it, which explains the peaks of surface ozone in these months. When averaged over whole China, CPO contributes about $20 \%$ of TO in summer. However, the spatial variability in CPO reaches up to $100 \%$, as CPO accounts for much larger fractions over regions with large emissions.

As it is not appropriate to generalize one seasonal pattern for surface ozone that can fit for all parts of China, we focus our analysis of seasonality over four different regions in China: West China (WC), Northeastern China (NEC), North China (NC), and South China (SC). NBO show distinct peaks in the spring over all four regions, reflecting the influence of STE on natural ozone background over the northern middle latitudes (Fig. 10, right panels). In spring, NBO ranges from $45 \mathrm{ppbv}$ averaged over WC to $30 \mathrm{ppbv}$ over SC. The spring peak of surface ozone over WC and NEC is attributed to that of NBO. PBO shows distinct troughs in summer over all four regions. This can be explained in part by the decrease in the lifetime of ozone and its precursors in the summer and in part by summer monsoonal circulation which brings marine air masses with lower ozone to China. Monthly mean PBO ranges from 5 to $17 \mathrm{ppb}$ depending on region and season. PBO peaks in the spring over all regions 
due to longer $\mathrm{O}_{3}$ lifetime and larger influx of European pollution. As the combination of $\mathrm{NBO}$ and $\mathrm{PBO}, \mathrm{TBO}$ has a maximum in spring and minimum in summer over all four regions. On the monthly-mean basis, CPO exceeds anthropogenic background only in the summer and fall over $\mathrm{NC}$ and $\mathrm{SC}$ where domestic emissions are large. The summertime trough in ozone over eastern China (SC and NC) is driven by the decrease of background ozone (by the regional-average of -15 ppbv), despite of the fact that CPO shows an increase from spring to summer.

Tagged simulations suggest that the summertime decrease in background ozone is a result of reduced transport from northern middle latitude continents including EU and NA, whereas ozone from Southeast Asia exhibits a maximum in the summer. This contrast in seasonality provides clear evidence that it is the seasonal switch in monsoonal wind patterns that plays a significant role in determining the seasonality of background ozone over China. The northwesterly monsoon brings polluted continental air masses with higher ozone levels in the spring and fall. It switches to southwesterly in the summer bringing in relatively clean marine air masses from the south. NA and $\mathrm{EU} \mathrm{O}_{3}$ in combination result in a decrease of 4-8 ppbv from spring to summer over different regions in China, more than offsetting an increase of less than $2 \mathrm{ppb}$ resulting from $\mathrm{SEA} \mathrm{O}_{3}$ during the same period. $\mathrm{O}_{3}$ from ROW contributes to a further decrease of about 8 ppbv from spring to summer. As a result, background ozone shows a distinct summer minimum over all regions of China. The tagged ozone simulation indicates that the influence from foreign source regions differ in different receptor regions. For example, the maximum monthly-mean influence of EU ozone ranges from $2 \mathrm{ppb}$ in $\mathrm{SC}$ in the summer to $6 \mathrm{ppb}$ in NEC in the spring.

The focus of our analysis is on the influence of different source regions and source types on monthly-mean and regional-averaged abundance of surface ozone over China. Another aspect is on these source regions/types on the dayto-day variability of surface ozone and the implications on air quality management. Although it is not in the scope of our study, this topic is of great importance and will be studied in our subsequent research.

Acknowledgements. This research was supported by the National Science Foundation of China (grant No. 41005060) and by the National High Technology Research and Development Program of China (Grant No. 2009AA122005). Y. Wang acknowledges additional support by Tsinghua University Initiative Scientific Research Program. We thank two anonymous reviewers for their helpful comments.

Edited by: N. Riemer

\section{References}

Akimoto, H.: Global air quality and pollution, Science, 302(5651), 1716-1719, 2003.

Auvray, M. and Bey, I.: Long-range transport to Europe: Seasonal variations and implications for the European ozone budget, J. Geophys. Res., 110, D11303, doi:10.1029/2004jd005503, 2005.

Beer, R.:, TES on the Aura Mission: Scientific Objectives, Measurements, and Analysis Overview, IEEE T. Geosci. Remote, 44, 1102-1105, 2006.

Benkovitz, C. M., Scholtz, M. T., Pacyna, J., Tarrason, L., Dignon, J., Voldner, E. C., Spiro, P. A., Logan, J. A., and Graedel, T. E.: Global gridded inventories of anthropogenic emissions of sulfur and nitrogen, J. Geophys. Res., 101(D22), 29239-29253, 1996.

Derwent, R. G., Collins, W. J., Johnson, C. E., and Stevenson, D. S.: Transient behaviour of tropospheric $\mathrm{O}_{3}$ precursors in a global 3D CTM and their indirect greenhouse effects, Climatic Change, 49(4), 463-487, doi:10.1023/A:1010648913655, 2001.

Bey, I., Jacob, D. J., Yantosca, R. M., Logan, J. A., Field, B. D., Fiore, A. M., Li, Q. B., Liu, H. Y., Mickley, L. J., and Schultz, M. G.: Global modeling of tropospheric chemistry with assimilated meteorology: Model description and evaluation, J. Geophys, Res., 106(D19), 23073-23095, 2001a.

Bey, I., Jacob, D. J., Logan, J. A., and Yantosca, R. M.: Asian chemical outflow to the Pacific origins, pathways and budgets, J. Geophys. Res., 106(D19), 23097-23113, 2001b.

Chen, D., Wang, Y., McElroy, M. B., He, K., Yantosca, R. M., and Le Sager, P.: Regional CO pollution and export in China simulated by the high-resolution nested-grid GEOS-Chem model, Atmos. Chem. Phys., 9, 3825-3839, doi:10.5194/acp-9-3825-2009, 2009.

Duncan, B. N., Martin, R. V., Staudt, A. C., Yevich, R., and Logan, J. A.: Interannual and seasonal variability of biomass burning emissions constrained by satellite observations, J. Geophys. Res., 108(D2), 4100, doi:10.1029/2002JD002378, 2003.

Fiore, A., Jacob, D. J., Bey, I., Yantosca, R. M., Field, B. D., Fusco, A. C., and Wilkinson, J. G.: Background ozone over the United States in summer: Origin, trend, and contribution to pollution episodes, J. Geophys. Res., 107, D154275, doi:10.1029/2001JD000982, 2002.

Fiore, A., Jacob, D. J., Liu, H., Yantosca, R. M., Fairlie, T. D., and $\mathrm{Li}, \mathrm{Q}$.: Variability in surface ozone background over the United States: Implications for air quality policy, J. Geophys. Res., 108(D24), 4787, doi:10.1029/2003JD003855, 2003.

Fiore, A. M., Dentener, F. J., Wild, O., Cuvelier, C., Schultz, M. G., Hess, P., Textor, C., Schulz, M., Doherty, R. M., Horowitz, L. W., MacKenzie, I. A., Sanderson, M. G., Shindell, D. T., Stevenson, D. S., Szopa, S., Van Dingenen, R., Zeng, G., Atherton, C., Bergmann, D., Bey, I., Carmichael, G., Collins, W. J., Duncan, B. N., Faluvegi, G., Folberth, G., Gauss, M., Gong, S., Hauglustaine, D., Holloway, T., Isaksen, I. S. A., Jacob, D. J., Jonson, J. E., Kaminski, J. W., Keating, T. J., Lupu, A., Marmer, E., Montanaro, V., Park, R. J., Pitari, G., Pringle, K. J., Pyle, J. A., Schroeder, S., Vivanco, M. G., Wind, P., Wojcik, G., Wu, S., and Zuber, A.: Multimodel estimates of intercontinental sourcereceptor relationships for ozone pollution, J. Geophys. Res., 114, D04301, doi:10.1029/2008JD010816, 2009.

Guenther, A., Karl, T., Harley, P., Wiedinmyer, C., Palmer, P. I., and Geron, C.: Estimates of global terrestrial isoprene emissions using MEGAN (Model of Emissions of Gases and Aerosols from 
Nature), Atmos. Chem. Phys., 6, 3181-3210, doi:10.5194/acp-63181-2006, 2006.

Han, Z., Sakurai, T., Ueda, H., Carmichael, G. R., Streets, D. G., Hayami, H., Wang, Z., Holloway, T., Engardt, M., Hozumi, Y., Park, S.U., Kajino, M., Sartelet, K., Fung, C., Beneet, C., Thongboonchoo, N., Tang, Y., Chang, A., Matsuda, K., and Amann M.: MICS-Asia II: Model intercomparison and evaluation of ozone and relevant species, Atmos. Environ., 42, 3491-3509, doi:10.1016/j.atmosenv.2007.07.031, 2008.

Holloway, T., Sakurai, T., Han, Z., Ehlers, S., Spak, S. N., Horowitz, L. W., Carmichael, G. R., Streets, D. G., Hozumi, Y., Ueda, H., Park, S. U., Fung, C., Kajino, M., Thongboonchoo, N., Engardt, M., Bennet, C., Hayami, H., Sartelet, K., Wang, Z., Matsuda, K., and Amann, M.: MICS-Asia II: Impact of global emissions on regional air quality in Asia, Atmos. Environ., 42, 3543-3561, doi:10.1016/j.atmosenv.2007.10.022, 2008.

Jacob, D. J., Crawford, J. H., Kleb, M. M., Connors, V. S., Bendura, R. J., Raper, J. L., Sachse, G. W., Gille, J. C., Emmons, L., and Heald, C. L.: Transport and Chemical Evolution over the Pacific (TRACE-P) aircraft mission: Design, execution, and first results, J. Geophys. Res., 108, D209000, doi:10.1029/2002JD003276, 2003.

Li, J., Wang, Z. F., Akimoto, H., Chao, G., Pochanart, P., and Wang, X.: Modeling study of ozone seasonal cycle in lower troposphere over east Asia, J. Geophys. Res., 112, D22S25, doi:10.1029/2006JD008209, 2007.

Lin, M., Holloway, T., Oki, T., Streets, D. G., and Richter, A.: Multi-scale model analysis of boundary layer ozone over East Asia, Atmos. Chem. Phys., 9, 3277-3301, doi:10.5194/acp-93277-2009, 2009.

Liu, H. Y., Jacob, D. J., Chan, L. Y., Oltmans, S. J., Bey, I., Yantosca, R. M., Harris, J. M., Duncan, B. N., and Martin, R. V.: Sources of tropospheric ozone along the Asian Pacific Rim: An analysis of ozonesonde observations, J. Geophys. Res., 107, D214573, doi:10.1029/2001JD002005, 2002.

Liu, X., Chance, K., Sioris, C. E., Kurosu, T. P., Spurr, R. J. D., Martin, R. V., Fu, T., Logan, J. A., Jacob, D. J., Palmer, P. I., Newchurch, M. J., Megretskaia, I. A., and Chatfield, R. B.: First directly retrieved global distribution of tropospheric column ozone from GOME: Comparison with the GEOS-CHEM model, J. Geophys. Res., 111, D02308, doi:10.1029/2005JD006564, 2006.

Luo, M., Rinsland, C., Fisher, B., Sachse, G., Diskin, G., Logan, J., Worden, H., Kulawik, S., Osterman, G., Eldering, A., Herman, R., and Shephard, M.: TES carbon monoxide validation with DACOM aircraft measurements during INTEX-B 2006, J. Geophys. Res., 112, D24S48, doi:10.1029/2007JD008803, 2007.

Nagashima, T., Ohara, T., Sudo, K., and Akimoto, H.: The relative importance of various source regions on East Asian surface ozone, Atmos. Chem. Phys., 10, 11305-11322, doi:10.5194/acp10-11305-2010, 2010.

Nassar, R., Logan, J. A., Worden, H. M., Megretskaia, I. A., Bowman, K. W., Osterman, G. B., Thompson, A. M., Tarasick, D. W., Austin, S., Claude, H., Dubey, M. K., Hocking,W. K., Johnson, B. J., Joseph, E., Merrill, J., Morris, G. A., Newchurch, M., Oltmans, S. J., Posny, F., Schmidlin, F. J., Vomel, H., Whiteman, D. N., and Witte, J. C.: Validation of Tropospheric Emission Spectrometer (TES) nadir ozone profiles using ozonesonde measurements, J. Geophys. Res., 113, D15S17,
doi:10.1029/2007JD008819, 2008.

Newell, R. E. and Evans, M. J.: Seasonal changes in pollutant transport to the North Pacific: the relative importance of Asian and European sources, Geophys. Res. Lett., 27(16), 2509-2512, 2000.

Park, R. J., Jacob, D. J., Field, B. D., Yantosca, R. M., and Chin, M.: Natural and transboundary pollution influences on sulfate-nitrate-ammonium aerosols in the United States: Implications for policy, J. Geophys. Res., 109, D15204, doi:10.1029/2003JD004473, 2004.

Piccot, S. D., Watson, J. J., and Jones, J. W.: A Global inventory of volatile organic-compound emissions from anthropogenic sources, J. Geophys. Res., 97(D9), 9897-9912, 1992.

Pickering, K. E., Wang, Y., Tao W. K., Price, C., and Müler, J. F.: Vertical distributions of lightning $\mathrm{NO}_{\mathrm{x}}$ for use in regional and global chemical transport models, J. Geophys. Res., 103(D23), 31203-31216, 1998.

Pochanart, P., Akimoto, H., and Kajii, Y.: Regional background ozone and carbon monoxide variations in remote Siberia/East Asia, J. Geophys. Res., 108, D14028, doi:10.1029/2001JD001412, 2003.

Price, C. and Rind, D.: A Simple Lightning Parameterization for Calculating Global Lightning Distributions, J. Geophys. Res., 97(D9), 9919-9933, 1992.

Sauvage, B., Martin, R. V., van Donkelaar, A., Liu, X., Chance, K., Jaeglé, L., Palmer, P. I., Wu, S., and Fu, T.-M.: Remote sensed and in situ constraints on processes affecting tropical tropospheric ozone, Atmos. Chem. Phys., 7, 815-838, doi:10.5194/acp-7-815-2007, 2007.

Streets, D., Bond, T., Carmichael, G. R., Fernandes, S. D., Fu, Q., He, D., Klimont, Z., Nelson, S. M., Tsai, N. Y., Wang, M. Q., Woo, J.-H., and Yarber, K. F.: An inventory of gaseous and primary aerosol emissions in Asia in the year 2000, J. Geophys. Res., 108(D21), 8809, doi:10.1029/2002JD003093, 2003.

van der Werf, G. R., Randerson, J. T., Giglio, L., Collatz, G. J., Kasibhatla, P. S., and Arellano Jr., A. F.: Interannual variability in global biomass burning emissions from 1997 to 2004, Atmos. Chem. Phys., 6, 3423-3441, doi:10.5194/acp-6-3423-2006, 2006.

Wang, H. Q., Jacob, D. J., Le, S. P., Streets, D. G., Park, R. J., Gilliland, A. B., and van Donkelaar, A.: Surface ozone background in the United States: Canadian and Mexican pollution influences, Atmos. Environ., 43(6), 1310-1319, 2008.

Wang, T., Cheung, V., Anson, C. M., and Li, Y. S.: Ozone and related gaseous pollutants in the boundary layer of eastern China: Overview of the recent measurements at a rural site, Geophys. Res. Lett., 28(12), 2373-2376, 2001.

Wang, T., Cheung, T. F., Li, Y. S., Xu, X. M., and Blake, D. R.: Emission characteristics of $\mathrm{CO}, \mathrm{NO}_{\mathrm{X}}, \mathrm{SO} 2$ and indications of biomass burning observed at a rural site in eastern China, J. Geophys. Res., 107(D12), 4157, doi:10.1029/2001JD000724, 2002.

Wang, T., Wei, X. L., Ding, A. J., Poon, C. N., Lam, K. S., Li, Y. S., Chan, L. Y., and Anson, M.: Increasing surface ozone concentrations in the background atmosphere of Southern China, 19942007, Atmos. Chem. Phys., 9, 6217-6227, doi:10.5194/acp-96217-2009, 2009.

Wang, Y. H. and Jacob, D. J.: Anthropogenic forcing on tropospheric ozone and $\mathrm{OH}$ since preindustrial times, J. Geophys. Res., 103(D23), 31123-31135, 1998a. 
Wang, Y. H., Jacob, D. J., and Logan, J. A.: Global simulation of tropospheric $\mathrm{O} 3-\mathrm{NO}_{\mathrm{x}}$-hydrocarbon chemistry.1, Model formulation, J. Geophys. Res., 103(D9), 10713-10716, 1998 b.

Wang, Y. H., Jacob, D. J., and Logan, J. A.: Global simulation of tropospheric $\mathrm{O} 3-\mathrm{NO}_{\mathrm{x}}$-hydrocarbon chemistry. 3. Origin of tropospheric ozone and effects of nonmethane hydrocarbons, J. Geophys, Res., 103(D9), 10757-10767, 1998c.

Wang, Y. X., McElroy, M. B., Jacob, D. J., and Yantosca, R. M.: A nested grid formulation for chemical transport over Asia: Applications to CO, J. Geophys. Res., 109, D22307, doi:10.1029/2004JD005237, 2004a.

Wang, Y. X., McElroy, M. B., Wang, T., and Palmer, P. I.: Asian emissions of $\mathrm{CO}$ and $\mathrm{NO}_{\mathrm{X}}$ : Constraints from aircraft and Chinese station data, J. Geophys. Res., 109, D24304, doi:10.1029/2004JD005250, 2004b.

Wang, Y. X., McElroy, M. B., Martin, R. V., Streets, D. G., Zhang, Q., and Fu, T. M.: Seasonal variability of $\mathrm{NO}_{\mathrm{x}}$ emissions over east China constrained by satellite observations: Implications for combustion and microbial sources, J. Geophys. Res., 112, D06301, doi:10.1029/2006JD007538, 2007a.

Wang, Y. X., McElroy, M. B., Boersma, K. F., Eskes, H. J., and Veefkind, J. P.: Traffic restrictions associated with the Sino-African summit: Reductions of $\mathrm{NO}_{\mathrm{x}}$ detected from space, Geophys. Res. Lett., 34, L08814, doi:10.1029/2007GL029326, $2007 b$.

Wang, Y., McElroy, M. B., Munger, J. W., Hao, J., Ma, H., Nielsen, C. P., and Chen, Y.: Variations of $\mathrm{O}_{3}$ and $\mathrm{CO}$ in summertime at a rural site near Beijing, Atmos. Chem. Phys., 8, 6355-6363, doi:10.5194/acp-8-6355-2008, 2008.

Wang, Y. X., Zhang, Y., and Hao, J.: Review on the applications of Tropospheric Emissions Spectrometer to air-quality research: Perspectives for China, Frontiers of Environmental Science \& Engineering in China, 4(1), 12-19, doi:10.1007/s11783010-0012-9, 2010a.
Wang, Y., Munger, J. W., Xu, S., McElroy, M. B., Hao, J., Nielsen, C. P., and Ma, H.: $\mathrm{CO}_{2}$ and its correlation with $\mathrm{CO}$ at a rural site near Beijing: implications for combustion efficiency in China, Atmos. Chem. Phys., 10, 8881-8897, doi:10.5194/acp-10-88812010, 2010b.

Wild, O. and Akimoto, H.: Intercontinental transport of ozone and its precursors in a three-dimensional global CTM, J. Geophys. Res., 106(D21), 27729-27744, 2001.

Wild, O., Prather, J. M., and Akimoto, H.: Indirect long-term global radiative cooling from $\mathrm{NO}_{\mathrm{x}}$ emissions, Geophys. Res. Lett., 28(9), 1719-1722, 2001.

Wild, O., Pochanart, P., and Akimoto, H.: Trans-Eurasian transport of ozone and its precursors, J. Geophys. Res., 109, D11302, doi:10.1029/2003JD004501, 2004.

Wu, S., Duncan, B. N., Jacob, D. J., Fiore, A. M., and Wild, O.: Chemical nonlinearities in relating intercontinental ozone pollution to anthropogenic emissions, Geophys. Res. Lett., 36, L05806, doi:10.1029/2008GL036607, 2009.

Yienger, J. J. and Levy, H.: Empirical model of global soil-biogenic NO x emissions, J. Geophys. Res., 100(D6), 11447-11464, 1995.

Zhang, Q., Streets, D. G., Carmichael, G. R., He, K. B., Huo, H., Kannari, A., Klimont, Z., Park, I. S., Reddy, S., Fu, J. S., Chen, D., Duan, L., Lei, Y., Wang, L. T., and Yao, Z. L.: Asian emissions in 2006 for the NASA INTEX-B mission, Atmos. Chem. Phys., 9, 5131-5153, doi:10.5194/acp-9-5131-2009, 2009.

Zhao, C., Wang, Y., Yang, Q., Fu, R., Cunnold, D., and Choi, Y.: Impact of East Asian summer monsoon on air quality over China: The view from space, J. Geophys. Res., 115, D09301, doi:10.1029/2009JD012745, 2010. 